Mеталлофиз. новейшие технол. / Metallofiz. Noveishie Tekhnol. (C) 2016 ИМФ (Институт металлофизики 2016, т. 38, № 10, сc. 1379-1393/ DOI: 10.15407/mfint.38.10.1379 им. Г. В. Курдюмова НАН Украины) Оттиски доступны непосредственно от издателя

Фотокопирование разрешено только

Напечатано в Украине.

в соответствии с лицензией

PACSnumbers: 03.50.De, 41.20.Gz, 75.10.-b, 75.30.Gw, 75.60.Ch, 75.70.Kw, 81.65.Cf

\title{
Periodic Modulations of Magnetostatic Field in Ferromagnetic Cylinder and Their Influence on Etching Figure Formation in Acid Solutions
} \author{
and Yu. I. Gorobets \\ Institute of Magnetism, N.A.S. and M.E.S. of Ukraine, \\ $36^{\underline{b}}$ Academician Vernadsky Blvd., \\ UA-03142 Kyiv, Ukraine \\ "National Technical University of Ukraine ' $K P I$ ', \\ 37 Peremogy Ave., \\ UA-03056 Kyiv, Ukraine
}

Yu. I. Dzhezherya, O. Yu. Gorobets*, O. P. Kuz*, O. S. Klymuk*,

Ordinary cylindrical specimens with easy-axis anisotropy perpendicular to the axis of a cylinder are studied. As shown, the inhomogeneous long-wave magnetic configurations of harmonic type can be created and observed in such samples. A linear theory is developed to simplify the set of LandauLifshitz and Maxwell's equations to one general equation for a magnetostatic potential. The ranges of magnetic fields and the self-parameters responsible for the inhomogeneous periodic configuration formation are determined when solving a boundary value problem for a magnetostatic potential. Dependence of the period of magnetization wave on a magnetic field value, the constant of anisotropy and diameter of a cylinder is determined. The proposed theory gives qualitative explanation of the experiment when, using the Bitter's powder-like figures' method, quasi-periodic distributions of the magnetostatic fields can be observed in samples. These fields arise under external magnetic field of about $1 \mathrm{kOe}$ directed along the axis of a steel cylinder and are absent without external magnetic field. An example of practical application of long-wave magnetic structures for a surface morphology control during chemical etching of ferromagnetic metals in acid solutions is given.

Corresponding author: Yuri Ivanovich Dzhezherya

E-mail: dui_kpi@ukr.net

Please cite this article as: Yu. I. Dzhezherya, O. Yu. Gorobets, O. P. Kuz, O. S. Klymuk, and Yu. I. Gorobets, Periodic Modulations of Magnetostatic Field in Ferromagnetic Cylinder and Their Influence on Etching Figure Formation in Acid Solutions, Metallofiz. Noveishie Tekhnol., 38, No. 10: 1379-1393 (2016), DOI: $10.15407 /$ mfint.38.10.1379. 
The quasi-periodic structure of a corrosion surface of ferromagnetic cylinder corresponds to the period of a long-range magnetic structure.

Key words: ferromagnets, domain structure, magnetostatic field, etching.

Досліджено циліндричні зразки з легковісною анізотропією, перпендикулярною до осі циліндру. Показано, що в таких зразках можна створювати і спостерігати неоднорідні довгохвильові магнетні конфігурації гармонічного типу. Було розвинуто лінійну теорію, яка зводить систему рівнянь Ландау-Ліфшиця та Максвеллових, що описують магнетний стан системи, до одного загального рівняння для магнетостатичного потенціялу. В ході розв'язання крайової задачі для магнетостатичного потенціялу визначено діяпазон магнетних полів і власних параметрів системи, за яких ймовірним є утворення неоднорідної періодичної конфігурації. Визначено залежність періоду хвилі намагнетованости від амплітуди магнетного поля, константи анізотропії та діяметра циліндру. Запропонована теорія дає якісне пояснення експерименту, коли при застосуванні Біттерової методи порошкових фігур можливе спостереження квазиперіодичних розподілів магнетостатичних полів, що утворені при прикладанні зовнішнього магнетного поля порядку $1 \mathrm{\kappa E}$ вздовж осі сталевого циліндру, тоді як без прикладання зовнішнього магнетного поля магнетостатичні поля відсутні. Наведено приклад практичного застосування довгохвильових магнетних структур для керування морфологією поверхні при хемічному щавленні феромагнетних металів у розчинах кислот. При цьому квазиперіодична структура поверхні кородованого феромагнетного циліндра відповідає періоду його довгомасштабної магнетної структури.

Ключові слова: феромагнетики, доменна структура, магнетостатичне поле, щавлення.

Исследованы цилиндрические образцы с легкоосной анизотропией, перпендикулярной оси цилиндра. Показано, что в таких образцах можно создать и наблюдать неоднородные длинноволновые магнитные конфигурации гармонического типа. Развита линейная теория, которая сводит систему уравнений Ландау-Лифшица и Максвелла, описывающих магнитное состояние системы, к одному общему уравнению для магнитостатического потенциала. В ходе решения краевой задачи для магнитостатического потенциала определён диапазон магнитных полей и собственных параметров системы, при которых вероятным является образование неоднородной периодической конфигурации. Определена зависимость периода волны намагниченности от амплитуды магнитного поля, константы анизотропии и диаметра цилиндра. Предложенная теория даёт качественное объяснение эксперимента, когда при применении метода порошковых фигур Биттера возможно наблюдение квазипериодических распределений магнитостатических полей, образованных при воздействии внешнего магнитного поля порядка $1 \mathrm{kE}$ вдоль оси стального цилиндра, в то время как без приложения внешнего магнитного поля магнитостатические поля отсутствуют. Приведён пример практического использования длинноволновых магнитных структур для управления морфологией поверхности при химическом травлении ферромагнитных ма- 
териалов в растворах кислот. При этом квазипериодическая структура поверхности корродированного ферромагнитного цилиндра соответствует периоду его длинномасштабной структуры.

Ключевые слова: ферромагнетики, доменная структура, магнитостатическое поле, травление.

(Received September 12, 2016)

\section{INTRODUCTION}

Ferromagnetic materials are known to possess domain structure due to competition of magnetic interactions of the certain types. On the one hand, it is the energy of a magnetic anisotropy and exchange interaction; on the other hand, it is dipole-dipole interaction of magnetic moments of the system. Domain structure acquires the various forms depending on the contribution of the mentioned interactions, a specimen shape and characteristics of external magnetic field [1-4]. It can be a system of stripe domains, serpentine domain structure, a lattice of cylindrical domains, spiral domains, etc. Similar structures appear spontaneously or artificially and correspond to an absolute or a local minimum of complete energy among the variety of magnetic configurations.

The parameters of certain types of domain structures (DS) and their separate elements have been widely studied both by experimental and theoretical methods, for example [1-6]. These papers report on thermodynamic properties of ferromagnetic materials, the influence of DS on their magnetization processes and their practical use in magnetic devices. Except the practical application, investigation of magnetic configurations is interesting itself in the theory of the non-linear equations and theirs soliton-like solutions.

There are some elements of domain structures describing system magnetization field distribution, which satisfy the joint solution of the magnetostatic equations and the Landau-Lifshitz non-linear equations. These are the Néel and Bloch one-dimensional domain walls, the Shirobokov stripe domain structure, and the Belavin-Polyakov twodimensional soliton configurations. However, for real systems with geometrical restrictions of the samples, the mentioned solutions could be considered only as certain approach to the real magnetic configurations. Certain simplifications are necessary to take into account factors of magnetic objects shape and a wide spectrum of magnetic interactions influence. One of the most useful simplifications consists in representation of a domain wall as geometrical boundary characterized by a surface energy.

A number of important domain configurations and their elements have been investigated due to this approach $[1,2,4]$. 
However, there are magnetic configurations with the fundamentally different magnetization distribution compared to traditional domain structures, which are formed in ferromagnetic systems under certain conditions. These are non-uniform magnetic configurations in systems with biaxial anisotropy.

Inhomogeneous magnetic ordering character of such configurations is caused by a demagnetizing field in the presence of exchange interaction. These structures are characterized by the sinusoidal type modulation of magnetization components. The existence of such structures in magnetic films or plates with anisotropy factor lower than unit, were predicted in papers [7, 8]. The inhomogeneous structure period dependence on the thickness and parameters of material was determined as well. The development of this theory was the discovery of a magnetic field influence on the magnetization distribution in such structures [9].

\section{THEORETICAL DETAILS}

\subsection{Problem Definition}

It will be shown further that the inhomogeneous long-wave magnetic configuration of harmonic type can be created and observed in cylindrical samples with 'easy magnetic plane' anisotropy, which is perpendicular to the axis of the cylinder. The necessary condition of sinusoidal modulations creation in such systems is the magnetic field directed along the cylinder axis.

\subsection{The Equation for the Magnetostatic Potential and the Distribution of Magnetization in Ferromagnetic Film}

We assume that the system is a ferromagnetic cylinder in an external magnetic field. The cylinder axis coincides with the direction of the field and is directed along $0 z$. It is supposed that while making such a sample form (by rolling or drawing), uniaxial anisotropy of 'easy magnetization' occurs in the material in plane that is perpendicular to the axis of the cylinder.

Thus, the magnetic energy density of the film material consists of the exchange interaction energy, the Zeeman energy and magnetic anisotropy energy and is given by:

$$
w_{M}=\frac{\alpha}{2}\left(\frac{\partial \mathbf{M}}{\partial x_{k}}\right)^{2}+\frac{\beta}{2} M_{z}^{2}-H M_{z},
$$

where $\alpha-a$ constant of exchange magnetic interaction, $\mathbf{M}-\mathbf{a}$ system 
magnetization vector, $\beta$-the uniaxial anisotropy constant, $H-$ magnetic field value in the direction of cylinder axis $0 z$.

In case of $\beta>0$, we have anisotropy of 'easy plane' ( $x 0 y$ plane).

The fragment of a cylindrical ferromagnetic sample is shown in Fig. 1.

As, in ferromagnetic systems at fixed temperature, the absolute value of magnetization is constant,

$$
\mathbf{M}^{2}=M_{x}^{2}+M_{y}^{2}+M_{z}^{2}=M_{0}^{2}=\text { const }
$$

(where $M_{0}$-the saturation magnetization), we can represent Eq. (1) in form:

$$
w_{M}=\frac{\alpha}{2}\left(\frac{\partial \mathbf{M}}{\partial x_{k}}\right)^{2}+\frac{\beta}{2}\left(M_{0}^{2}+M_{x}^{2}+M_{y}^{2}\right)-H M_{z} .
$$

Based on Eq. (2), we can express effective magnetic field determined through variation derivative:

$$
\mathbf{H}_{\text {eff }}=-\frac{\delta w_{M}}{\delta \mathbf{M}}-\nabla \psi_{i}=\alpha \Delta \mathbf{M}+\beta\left(M_{x} \mathbf{e}_{x}+M_{y} \mathbf{e}_{y}\right)-\nabla \psi_{i},
$$

where $\psi_{i}-\mathrm{a}$ potential of a magnetostatic field in the cylinder, $\Delta=\partial^{2} / \partial x_{i} \partial x_{i}$ - the Laplace operator, $\nabla \psi_{i}$-gradient of magnetostatic potential in the cylinder, describing demagnetizing field of the sample $\mathbf{H}_{i}^{m}=-\nabla \psi_{i}$.

Last term in Eq. (3) determines demagnetizing field caused by magnetization inhomogeneities. The first term $\alpha \Delta \mathbf{M}$ is caused by exchange interactions. When changing of the magnetization modulations at great space scale (for example, the radius of a cylinder), it makes small contribution and can be neglected.

Indeed, for cylindrical magnetic system of the radius $R$, we can estimate $\alpha \Delta \mathbf{M}$ as follows:

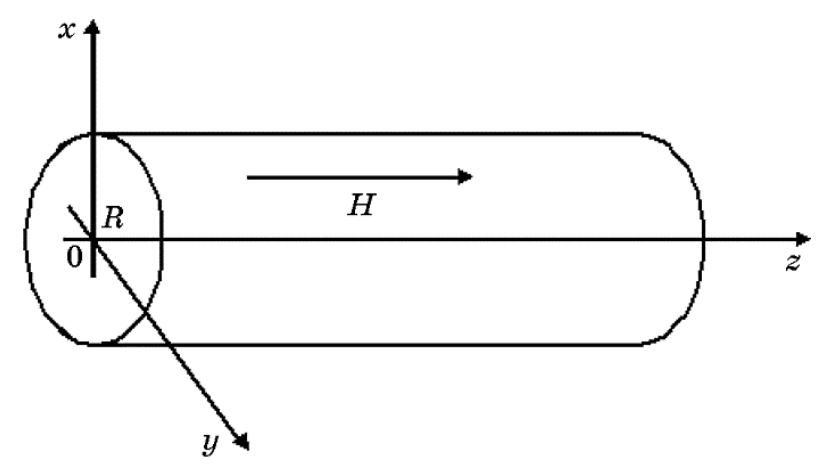

Fig. 1. The fragment of the ferromagnetic sample of a cylinder shape. 


$$
\alpha|\Delta \mathbf{M}| \sim \frac{\alpha \mathbf{M}}{R^{2}} \sim\left(\frac{\Lambda}{R}\right)^{2} M 4 \pi
$$

where $\Lambda=\sqrt{\alpha /(4 \pi)} \sim 10^{-4} \mathrm{~cm}$ - the characteristic magnetic length.

Thus, for ferromagnetic rods or wires of the diameter of $2 R \sim 10^{-2} \mathrm{~cm}$, the value of $\alpha|\Delta \mathbf{M}| \sim 4 \pi M \cdot 10^{-4}$ is of the same order with the terrestrial magnetic field.

The self-consistent distribution of magnetostatic fields and system magnetization in the cylinder is described by the Landau-Lifshitz and Maxwell's equation sets, which correspond to a static case:

$$
\begin{aligned}
& {\left[\mathbf{M} \times \mathbf{H}_{\text {eff }}\right]=0,} \\
& \operatorname{div} \mathbf{B}_{i}=0, \\
& \mathbf{B}_{i}=-\nabla \psi_{i}+H \mathbf{e}_{z}+4 \pi \mathbf{M}, \\
& \mathbf{H}_{\text {eff }}=-\nabla \psi_{i}+H \mathbf{e}_{z} .
\end{aligned}
$$

If the macroscopically modulations of a magnetization field with a wavelength close to the cylinder diameter are considered, then, the quantities with the second spatial derivatives in an effective field could be ignored, and the set of equations (4) will be as follows:

$$
\begin{aligned}
& M_{x}\left(\beta M_{y}-\partial \psi_{i} / \partial y\right)=M_{y}\left(\beta M_{x}-\partial \psi_{i} / \partial x\right), \\
& M_{x}\left(H-\partial \psi_{i} / \partial z\right)=M_{z}\left(\beta M_{x}-\partial \psi_{i} / \partial x\right), \\
& M_{y}\left(H-\partial \psi_{i} / \partial z\right)=M_{z}\left(\beta M_{y}-\partial \psi_{i} / \partial y\right), \\
& \Delta \psi_{i}=4 \pi \operatorname{div} \mathbf{M} .
\end{aligned}
$$

The potential $\psi_{e}$ and magnetic induction $\mathbf{B}_{e}$ satisfy to relations outside the sample:

$$
\begin{aligned}
& \Delta \psi_{e}=0, \\
& \mathbf{B}_{e}=-\nabla \psi_{e}+H \mathbf{e}_{z} .
\end{aligned}
$$

Requirements of the continuity of potential and the magnetic field component normal to the surface of the cylinder should be satisfied at the boundary of two media:

$$
\begin{gathered}
\psi_{i}=\left.\psi_{e}\right|_{r=R}, \\
-\frac{\partial \psi_{i}}{\partial r}+4 \pi M_{n}=-\left.\frac{\partial \psi_{e}}{\partial r}\right|_{r=R},
\end{gathered}
$$

where $M_{n}$-magnetization vector component normal to the cylinder surface. 
If magnetic field $H$ directed along cylinder axis is greater than anisotropy field, $H>\beta M_{0}$, then, ferromagnetic sample obtains homogeneous magnetization. Otherwise, $H<\beta M_{0}$, magnetization direction can deviate from the cylinder axis $0 z$.

Suppose that such deviations are negligibly small. So, $M_{z}=$ $=\sqrt{M_{0}^{2}-M_{x}^{2}-M_{y}^{2}} \approx M_{0}$. In such approximation, we excluded terms

$$
\left(M_{x} / M_{0}\right)^{2},\left(M_{y} / M_{0}\right)^{2}<<1 .
$$

Condition (8) is a soft constraint, because it allows operating with rather noticeable magnetization modulations: $\left|M_{x}\right|,\left|M_{y}\right| \sim 0.3 M_{0}$.

Considering that the magnetostatic potential changes are caused by magnetization modulations and have a small value as well, let us keep only the linear terms in the equations (4). As a result, the following relation is obtained between magnetization and magnetostatic potential components:

$$
4 \pi M_{x}=\frac{\partial \psi_{i} / \partial x}{Q-h}, 4 \pi M_{y}=\frac{\partial \psi_{i} / \partial y}{Q-h},
$$

where $h=H /\left(4 \pi M_{0}\right)$-a reduced magnetic field and $Q=\beta /(4 \pi)-$ a reduced anisotropy of the system.

Substituting the relation (9) in (4), the equation for magnetostatic potential is obtained in the self-contained view:

$$
\begin{aligned}
& a^{2}\left(\frac{\partial^{2} \psi_{i}}{\partial x^{2}}+\frac{\partial^{2} \psi_{i}}{\partial y^{2}}\right)-\frac{\partial^{2} \psi_{i}}{\partial z^{2}}=0, \\
& a^{2}=\frac{1-(Q-h)}{Q-h} .
\end{aligned}
$$

As a system possesses axial symmetry, it makes sense to represent equations (10) in a cylindrical coordinate system:

$$
a^{2}\left(\frac{1}{r} \frac{\partial}{\partial r} r \frac{\partial \psi_{i}}{\partial r}+\frac{1}{r^{2}} \frac{\partial^{2} \psi_{i}}{\partial \varphi^{2}}\right)-\frac{\partial^{2} \psi_{i}}{\partial z^{2}}=0,
$$

where $r=\sqrt{x^{2}+y^{2}}, \varphi=\operatorname{arctg}(y / x)$.

The equation (10) changes into wave one and can describe spontaneous modulation of magnetization of cylindrical sample, if the coefficient before a bracket has positive value. This condition can be presented as $0<Q-h<1$ or in initial designations:

$$
0<\beta M_{0}-H<4 \pi M_{0} \text {. }
$$


It follows from (11) that the magnetostatic wave structure cannot spontaneously be generated without magnetic field presence in a direction of system axis at large value of anisotropy when $\beta>4 \pi$. The requirement of occurrence of such magnetization modulation is carried out starting from some fixed value of the magnetic field.

Taking into account the relations (9), boundary conditions for the magnetostatic potential (7) on the surface of the cylinder gain the following meaning:

$$
\begin{aligned}
& \psi_{i}=\left.\psi_{e}\right|_{r=R}, \\
& a^{2} \frac{\partial \psi_{i}}{\partial r}=-\left.\frac{\partial \psi_{e}}{\partial r}\right|_{r=R} .
\end{aligned}
$$

Besides, the magnetic field on some distance from the sample should be converted in zero.

We will search for the solution of the boundary value problem (5), (10), (12) in case of the axial symmetry in the following form:

$$
\begin{aligned}
& \psi_{i}(r, z)=A J_{0}\left(\frac{k r}{a}\right) \cos k z, \\
& \psi_{e}(r, z)=B K_{0}(k r) \cos k z,
\end{aligned}
$$

where $J_{n}(x)$-the Bessel functions, and $K_{n}(x)$-McDonald's functions decaying at $r \rightarrow \infty, k$-a wave number, $A, B$-some constants defying amplitude of modulation.

The given functions turn the equation for the magnetostatic field potential to identity at any value of a wave number $k$.

The real value of $k$ is determined from the characteristic equation, which can be written out from the boundary conditions (12). Substituting (13) in relations for boundary conditions, the set of the homogeneous linear equations is obtained:

$$
\left(\begin{array}{cc}
J_{0}(k R / a) & -K_{0}(k R) \\
a J_{1}(k R / a) & K_{1}(k R)
\end{array}\right)\left(\begin{array}{l}
A \\
B
\end{array}\right)=\left(\begin{array}{l}
0 \\
0
\end{array}\right) .
$$

The requirement of non-zero solvability of the set (14) leads to the characteristic equation:

$$
J_{0}(k R / a) K_{1}(k R)+a J_{1}(k R / a) K_{0}(k R)=0 .
$$

The equation (15) has a discrete set of solutions concerning a wave number. We will be restricted by the definition of the minimum of $k$ value as the configurations with high values of wave numbers are characterised by greater energy at the account of an exchange interaction. 


\subsection{Discussion}

It follows from the Eq. (15) that the wave number depends on a magnetic field and anisotropy of a material. The dependences of modulation wavelengths on the quality factor $Q$ and magnetic field $h$ for the first numbers of a discrete spectrum are presented in Fig. 2.

Asymptotic behaviour of the magnetization wavelengths dependences on the external magnetic field can be easily obtained from the (15).

Thus, having $h \rightarrow Q$, we can get for the spectrum brunches:

$$
L_{n}=\frac{2 \pi R}{P_{n}} \sqrt{Q-h},
$$

where $P_{n}$-zeros of the Bessel function $J_{1}(x)$ :

$$
J_{1}\left(P_{n}\right)=0, P_{1}=3.817, P_{2}=7.0156, \ldots
$$

For the ferromagnetic systems with high anisotropy $Q>1$, we can get asymptotic behaviour at $h-(Q-1) \rightarrow 0$ :

$$
L_{n}=\frac{2 \pi R}{G_{n} \sqrt{h-(Q-1)}},
$$

where $G_{n}$-zeros of the Bessel function $J_{0}(x)$ :

$$
J_{0}\left(G_{n}\right)=0, G_{1}=2.4048, G_{2}=5.5201, \ldots
$$

It follows from the Eqs. (16), (17) that, at $h \rightarrow Q$ for any mode, the magnetostatic modulations wavelength tends to zero obeying squareroot law, while, for the systems with $Q \geq 1$ at $h-(Q-1) \rightarrow 0$, the wavelength asymptotically tends to $\infty$.

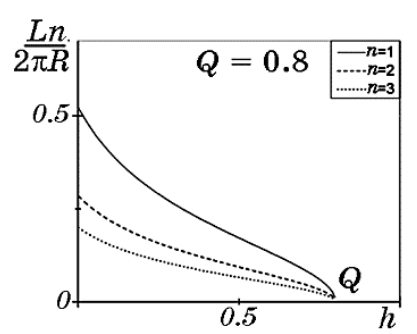

$a$

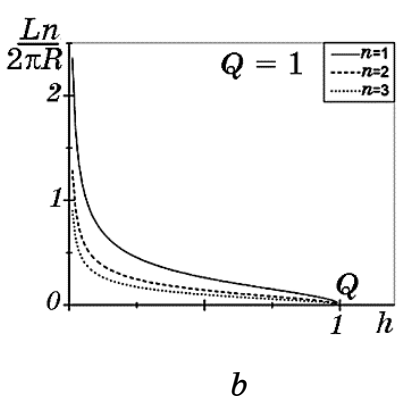

$b$

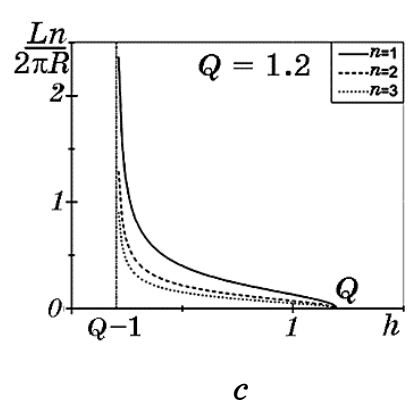

c

Fig. 2. Magnetostatic modulations wavelength dependence for several first modes of a spectrum. 


\section{EXPERIMENTAL DETAILS}

As it has been already mentioned, there are different types of lattices of magnetic domains in the ferromagnetic materials under certain conditions: the stripe domain structure, hexagonal lattices of cylindrical magnetic domains, etc. However, the situation is even more typical when there are more complicated inhomogeneous magnetization patterns in ferromagnets, for which existence of the large-scale quasiperiodic 'over-lattices' is typically observed 'against' micro scale periodic structure of magnetic domains.

For example, open domain structure with a magnetization direction perpendicular to the magnetic microwire surface [10]. As a rule, long ferromagnetic cylinder can have such configurations of domains that we can see not only the microscale domain structure for the amorphous magnetic micro wire but the quasi-periodic change of magnetization direction which is expressed in large-scale quasi-periodic change of the angle slope of magnetic domains concerning the symmetry axis of a microwire [10].

Similarly, the long-range magnetic structures of iron and steel cylinders with the Bitter's method application (a sedimentation method of highly dispersed paramagnetic powders $\left(\mathrm{Fe}_{2} \mathrm{O}_{3}\right)$ on a ferromagnetic surface from the distilled water) were revealed [11].

Magnetic structures observed experimentally in [11-16] for thin iron and steel cylinders are typical in comparison with the structures observed by other authors [10]. Such long-range domain structures of steel and iron cylinders as those have been shown in [11-16] can essentially affect the processes in electrolytes in the vicinity of their surfaces, in particular the processes of chemical etching in acids solutions.

In the present work with the use of the Bitter's powder-like figures' method, we have revealed the quasi-periodic distribution of magnetostatic fields formed by an external magnetic field of about 1-10 kOe applied along the axis of the steel cylinder and absent when the external magnetic field is not applied.

To investigate the magnetic field influence on the surface structure as a result of metal ferromagnet corrosion, we compared the steel cylinder surfaces as a result of corrosion in the solution of nitric acid without and with the magnetic field applied along the steel cylinder axis. Besides, the steel cylinders' surfaces under the experiments before the immersion on the solution were controlled by the optical microscope and the error of the medial diameter was less than 1 micron along the whole length.

For definiteness, let us consider typical change of the steel cylinder shape in a magnetic field in a nitric acid solution. The steel that the cylinder (DSTU 1050-88) has been made of, has the following composition: iron-98\%, other elements (nickel, copper, chrome, carbon, 


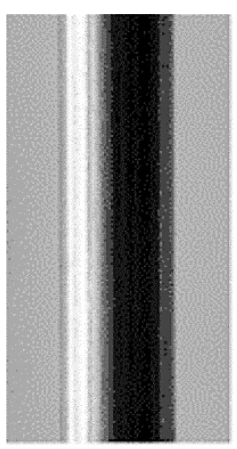

$a$

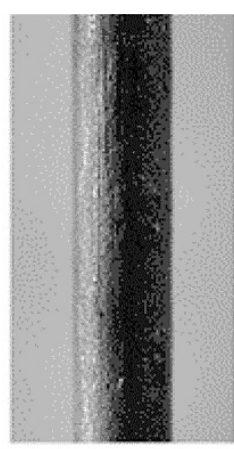

$b$

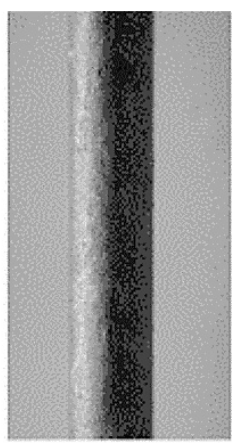

$c$

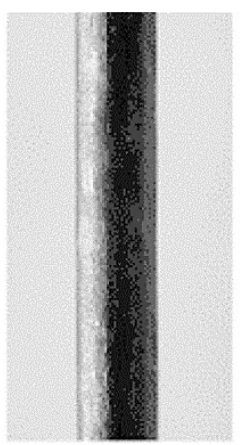

$d$

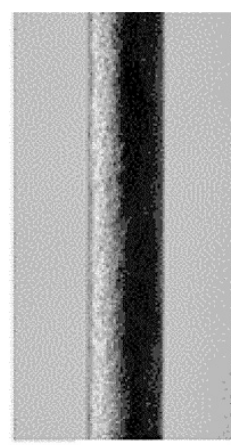

$200 \mu \mathrm{m}$

$e$

Fig. 3. The images of the initial cylinder $d=550 \mu \mathrm{m} \mathrm{(a)}$ and the cylinders after different duration of etching in a $7 \%$ solution of nitric acid without external magnetic field: $b-460 \mu \mathrm{m}, c-440 \mu \mathrm{m}, d-400 \mu \mathrm{m}, e-360 \mu \mathrm{m}$.

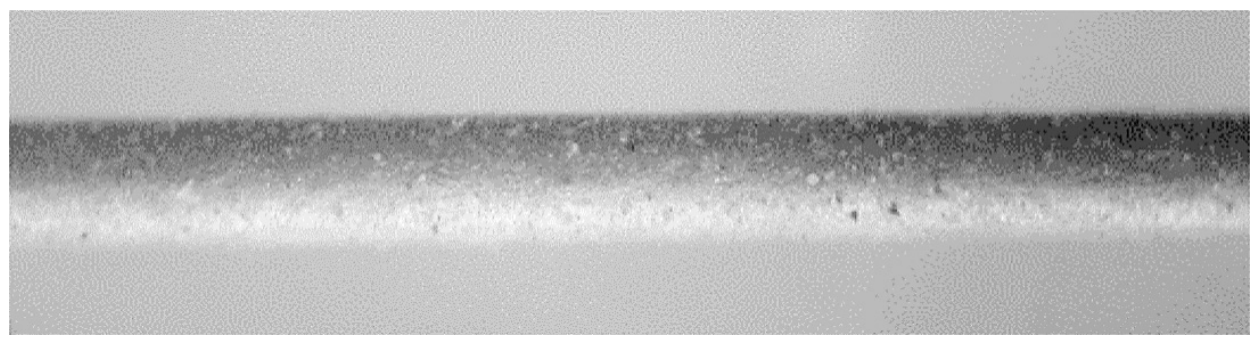

Fig. 4. Allocation of paramagnetic powder on a surface of the not magnetized cylinder of $D=440 \mu \mathrm{m}$.

phosphorus, sulphur, silicon, manganese)-2\%, and a surface before the experiment had smooth enough structure (Fig. 3,a), the cylinder length was equal to $18 \mathrm{~mm}$ in the experiments which results are given in Figs. 3, 4 and in Table 1.

The optical images of initial cylinder surface and cylinders after etching in 7\% water solution of nitric acid are given in Figs. 3, $b-e$.

It is clear that the cylinders corrode uniformly along the axis with formation of a smooth surface without appreciable dents and hills without external magnetic field. The diameter of cylinders along the axis within an error did not depend on coordinate.

Magnetostatic fields' distribution in dependence on initial diameter of a ferromagnetic cylinder was visualized by the Bitter's powder-like figures' method. The highly dispersed paramagnetic powder of iron oxide was used. Powder sedimentation was carried out with and without external magnetic field. Non-magnetized cylinders of different 
TABLE 1. The image of the powder figures and the etching figures depending on the cylinder diameter.

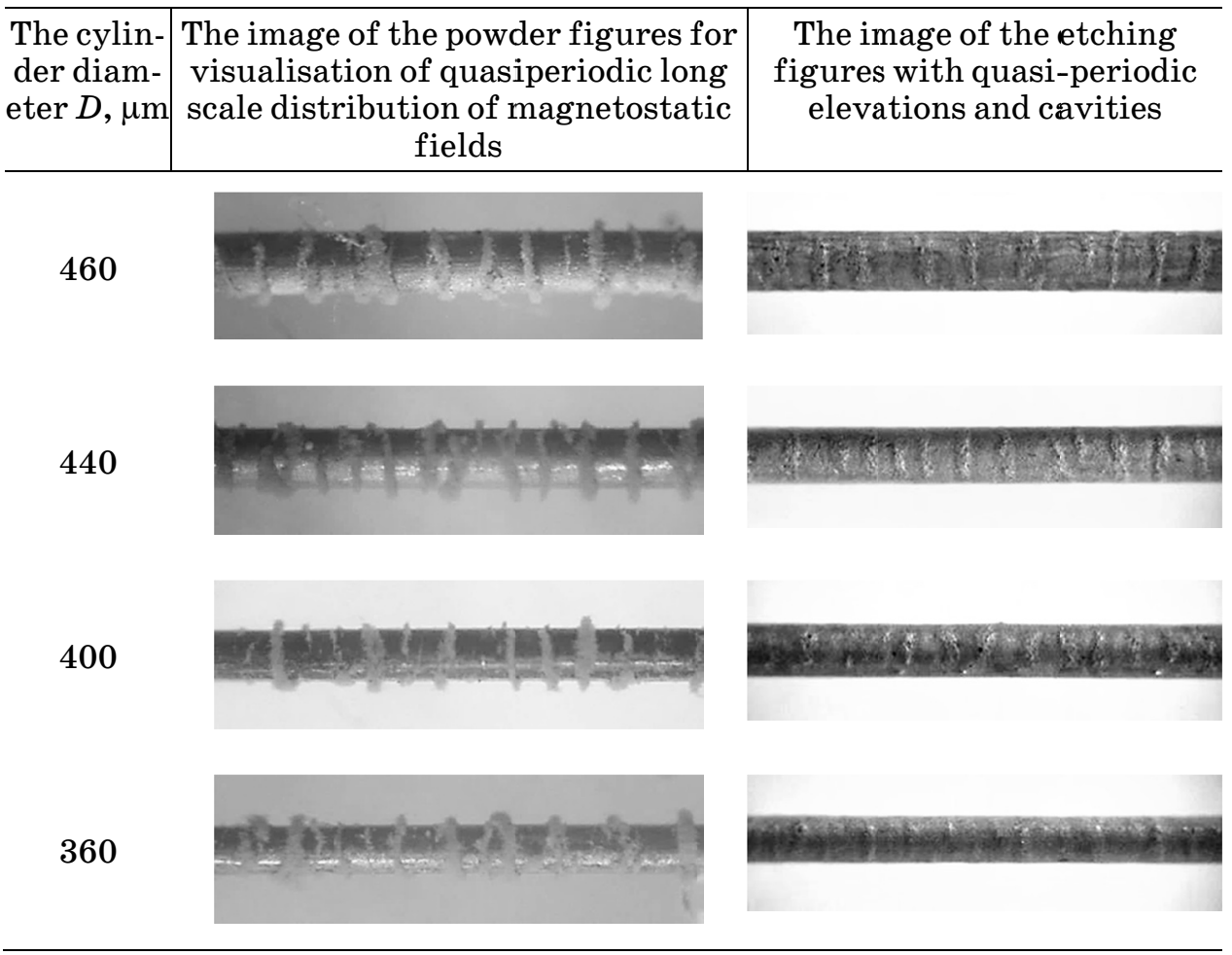

diameters were fastened on a thread and placed inside a cell for this purpose.

The $23 \mathrm{ml}$ of suspension containing a paramagnetic powder in the distilled water were added to the cell, which was outside of a magnetic system or in a constant homogeneous magnetic field. With magnetic field applied, the cylinder turned along its direction and was magnetized. The powder sedimentation on the cylinder was carried for $15 \mathrm{~min}$ until the saturation. The optical image of the cylinder with diameter $460 \mu \mathrm{m}$ after sedimentation of the paramagnetic powder without external magnetic field is given in Fig. 4.

It is clear from Fig. 4 that, without magnetic field, the large-scale periodic magnetic domain structure of the steel cylinder is not formed.

The average dimensional characteristics of the powder figures and the etching figures are given in Table 2.

According to the results, the width of elevations $L_{1}$, cavities $L_{2}$ and periods of the structures $L_{3}=L_{1}+L_{2}$ obtained by the method of powder figures and etching are identical within the error for steel cylinders of a wide range of diameters in external magnetic field for homo- 
TABLE 2. The average dimensional characteristics of the powder figures and the etching figures.

\begin{tabular}{|c|c|c|c|c|c|c|c|c|c|c|c|c|}
\hline \multirow{2}{*}{$\begin{array}{c}D, \\
\mu \mathrm{m}\end{array}$} & \multicolumn{6}{|c|}{$\begin{array}{c}\text { Dimensional characteristics } \\
\text { of the powder figures }\end{array}$} & \multicolumn{6}{|c|}{$\begin{array}{c}\text { Dimensional characteristics } \\
\text { of the etching figures }\end{array}$} \\
\hline & $\begin{array}{l}\left\langle L_{1}\right\rangle \\
\mu \mathrm{m}\end{array}$ & $\begin{array}{l}\sigma_{1}, \\
\mu \mathrm{m}\end{array}$ & $\begin{array}{c}\left\langle L_{2}\right\rangle, \\
\mu \mathrm{m}\end{array}$ & $\begin{array}{l}\sigma_{2}, \\
\mu \mathrm{m}\end{array}$ & $\begin{array}{l}\left\langle L_{3}\right\rangle \\
\mu \mathrm{m}\end{array}$ & $\begin{array}{l}\sigma_{3}, \\
\mu \mathrm{m}\end{array}$ & $\begin{array}{l}\left\langle L_{1}\right\rangle \\
\mu \mathrm{m}\end{array}$ & $\begin{array}{l}\sigma_{1}, \\
\mu \mathrm{m}\end{array}$ & $\begin{array}{c}\left\langle L_{2}\right\rangle, \\
\mu \mathrm{m}\end{array}$ & $\begin{array}{l}\sigma_{2}, \\
\mu \mathrm{m}\end{array}$ & $\begin{array}{c}\left\langle L_{3}\right\rangle, \\
\mu \mathrm{m}\end{array}$ & $\begin{array}{l}\sigma_{3}, \\
\mu \mathrm{m}\end{array}$ \\
\hline 460 & 100 & 10 & 240 & 20 & 340 & 30 & 100 & 10 & 230 & 30 & 320 & 30 \\
\hline 440 & 100 & 10 & 220 & 20 & 320 & 20 & 100 & 10 & 200 & 20 & 300 & 20 \\
\hline 400 & 110 & 10 & 220 & 30 & 320 & 30 & 110 & 10 & 200 & 20 & 310 & 20 \\
\hline 360 & 100 & 10 & 210 & 30 & 310 & 30 & 110 & 10 & 180 & 30 & 310 & 30 \\
\hline
\end{tabular}

geneous external magnetic field value $B=3 \mathrm{kG}$. The average width of elevations of the Bitter's powder figures and elevations of etching figures is about $100 \mu \mathrm{m}$. The length of cavities is about $200 \mu \mathrm{m}$. Therefore, the cavities are approximately twice wider than elevations. The length of period of the structures is approximately $300 \mu \mathrm{m}$.

The regions with the increased and decreased etching rates of ferromagnetic cylinder appear due to the inhomogeneous quasi-periodic magnetostatic-fields' distribution in the ferromagnetic cylinder. The nonuniform magnetic fields of cylinder domain structure create the nonuniform concentration distribution of paramagnetic or effectively paramagnetic cluster products of chemical etching [17] at the interface with an electrolyte that leads to the cylinder heterogeneity dissolution along the axis and to formation of the quasi-periodic structure on its surface [11-16].

The hysteresis curve of the steel cylinder is presented in Fig. 5. The

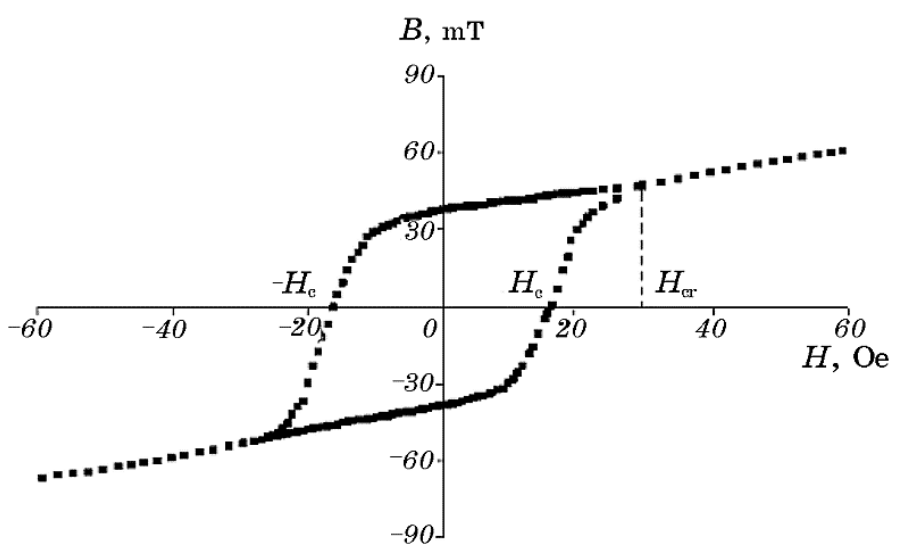

Fig. 5. The hysteresis curve of the steel cylinder, coercive force $H_{\mathrm{c}}=17 \mathrm{Oe}$. 
hysteresis curve comparison with the results of visualization of the large-scale distribution of magnetostatic fields by means of the powder figures gives the possibility to admit that the short-range non-regular domain structure with the sizes of separate domains less than the cylinder diameter exists in external magnetic fields, lower than critical field $H_{\text {cr }}$.

The process of cylinder magnetization is not terminated with the external magnetic field exceeding $H_{\mathrm{cr}}$, and the large-scale quasi-periodic domain structure is created, and the magnetization of the sample linearly grows at the subsequent increase of an external magnetic field.

\section{CONCLUSION}

It is shown for cylinders of different diameters (Table 2) that formation of etching figures under external magnetic field is caused by spatial distribution of their magnetostatic fields. As a result, it is shown in the present work for the steel cylinders of different diameter that the quasi-periodic structure of corrode surfaces is created during their chemical etching in a solution of nitric acid with the constant magnetic field applied, while the quasi-periodic structure of corrode surfaces is not formed under the same experimental conditions without magnetic field influence. Besides, the quasi-periodic structure of the cylinder that is observed due to its etching arises only on ferromagnetic samples and the characteristic period of the quasi-periodic structure equals to the period of the long-range magnetic structure of ferromagnetic sample.

The results of the present work prove experimentally the possibility of formation of inhomogeneous boundary conditions for the electric field potential and a current density, offered in [18], on an interface metal-electrolyte, if metal is spatially homogeneous with its chemical compound and mechanical properties.

\section{REFERENCES}

1. Ch. Kittel, Phys. Rev., 70, 965 (1946).

2. A. A. Thiele, Bell System Techn. J., 48: 3287 (1969).

3. A. H. Bobeck and E. Della Torre, Magnetic Bubbles (Amsterdam: North-Holland Publishing Co.: 1975).

4. A. P. Malozemoff and J. C. Slonczewski, Magnetic Domain Walls in Bubble Materials (New York: Academic Press: 1979).

5. A. N. Eschenfelder, Physics and Technology of Cylindrical Magnetic Domains (New York: Wiley: 1983).

6. J. A. Cape and G. W. Lehman, J.Appl. Phys., 42: 5732 (1971).

7. Yu. I. Dzhezherya, M. V. Sorokin, and O. O. Bubuk, Naukovi Visti NTUU 'KPI', 4: 51 (2006) (in Ukrainian). 
8. Yu. I. Dzhezherya, M. V. Sorokin, and E. A. Bubuk, Zh. Eksp. Teor. Fiz., 133: 844 (2007).

9. Yu. I. Dzhezherya and K. O. Demishev, Metallofiz. Noveishie Tekhnol., 34, No. 4: 429 (2012) (in Ukrainian).

10. Yu. Kabanov, A. Zukov, V. Zukova, and J. Gonzalez, International Conference 'Functional Materials' (Partenit, The Crimea, Ukraine, 2005), p. 66.

11. M. Yu. Ilchenko, S. V. Gorobets, O. Yu. Gorobets, and O. K. Dvoynenko, International Conference 'Functional Matetials' ICFM-2011 (Partenit, The Crimea, Ukraine, October 3-8, 2011), p. 393.

12. O. Yu. Gorobets, S. V. Gorobets, D. O. Derecha, and O. M. Brukva, J. Phys. Chem. C, 112: 3373 (2008).

13. O. Yu. Gorobets and D. O. Derecha, Mater. Sci., 24: 1017 (2007).

14. S. V. Gorobets, O. Yu. Gorobets, O. K. Dvoinenko, and G. L. Lebeda, Phys. Met. Metallogr., 113: 129 (2012).

15. S. V. Gorobets, O. Yu. Gorobets, S. P. Mazur, and A. A. Slusar, physica status solidi (c), 1: 3686 (2004).

16. S. V. Gorobets, O. Yu. Gorobets, and O. M. Brukva, Appl. Surf. Sci., 252/2: 448 (2005).

17. O. Yu. Gorobets, Yu. I. Gorobets, I. A. Bondar, and Yu. A. Legenkiy, J.Magn. Magn. Mater., 330: 76 (2013).

18. O. Yu. Gorobets, Yu. I. Gorobets, and V. P. Rospotnyuk, Metallofiz. Noveishie Tekhnol., 34, No. 7: 895 (2012) (in Ukrainian). 